Original Article

\title{
A Descriptive Study on Knowledge of Registered Nurses Regarding Hospital Protocols on Biomedical Waste and Spillage Management and Needle Stick Injury in a Selected Hospital
}

\author{
Pramila Dsouza', Savitha Pramilda Cutinho², Benita Reema D'Silva ${ }^{3}$, Lanisha Sharon D'Souza ${ }^{4}$, \\ Dainy Reshma D'Souza ${ }^{5}$, Janet Joy Joseph ${ }^{6}$, Neethu K.C. ${ }^{7}$, Rinu Susan Varghese ${ }^{8}$ \& Vanyakala M.N. ${ }^{9}$ \\ ${ }^{1}$ Lecturer, ${ }^{2}$ Head of the Department. ${ }^{3,4,5,6,7,8,9}$ Students, Department of Obstetrics and Gynecological Nursing, \\ Father Muller College of Nursing. Kankanady, Mangalore, Karnataka.
}

Correspondence

Pramila D'Souza

Lecturer, Department of Obstetrics and Gynecological Nursing, Father Muller College of Nursing, Kankanady, Mangalore, Karnataka. E-mail : prameela_dsouza@ rediffmail.com

\begin{abstract}
Background : Infection control is a major component in health care practices. The health care team while providing services of curative, promotive or preventive, inevitably create waste and also cause injury which may be hazardous to health. Poor waste management practices pose a huge risk to the health of public, patients, professionals and also contribute to environmental degradation. Nurses as the part of health care personnel is expected to have proper knowledge, practice, and capacity to guide others for waste collection, management, and proper handling techniques. ${ }^{6}$

Method : A descriptive study was conducted to assess the knowledge of nurses on biomedical waste Management, spillage management and to determine needle stick injury among 210 registered nurses working in various wards of selected hospital. The convenient sampling technique was used to select the subjects. Baseline proforma and structured knowledge questionnaire was used to collect the data and data wasanalyzed using descriptive and inferential statistics.
\end{abstract}

Result : In this study it has been found that the majority of staff nurses (78.6\%) had good level of knowledge,18.1\%had very good level of knowledge and 3.33\% had satisfactory level of knowledge on Biomedical Waste and Spillage Management and Needle Stick Injury.

Conclusion: The findings of the study have shown that majority of staff nurses have good level of knowledge on Biomedical Waste and Spillage Management and Needle Stick Injury.

Keywords : Knowledge, staff nurses, descriptive approach, Bio-Medical Waste Management (BMW), spillage management, management of needle stickinjury.

\section{Introduction}

All activities of living things on earth produce waste in some form or the other. Normally, aerobic and anaerobic process in the environment degrade such products. Hospitals and medical health centers are places to diffuse disease. Infectious situations at hospitals should

\begin{tabular}{|c|}
\hline Access this article online \\
\hline Quick Response Code \\
\hline
\end{tabular}
be a primary concern. Hospital waste cause many things to be at risk and lost, including h u m a $n$ I i f e, environmental health improper handling of and funds. Therefore solid waste in the hospital may increase the air borne pathogenic bacteria, which could adversely affect the hospital environment and community at large.

Waste generated from medical activities represents a real problem of living nature and human world. Improper management of waste generated in health care facilities causes a direct health impact on the community. In a hospital, management of spillage of hazardous substances such as bodily fluids, drugs, cleaning fluids and other chemicals are very essential. It is essential, therefore, the hospital should have the right equipment and well trained staff on hand to deal with any spills immediately when they arise. Needle 
stick injuries are a hazard for people who work in health care set up and these injuries can occur at any time when people use, disassemble or dispose of needles and can become a potential source of infection.

Through the 1990s, between 6 lakh and 8 lakh needle stick injuries were believed to occur annually - on the order of 2,000 every day. As a result, more than 1,000 health care workers contracted serious blood borne diseases.

In this aspect, the knowledge of nurses is important to prevent the spread of pathogens and microorganism and also serious health consequences. Nurses are a part of health care team who are constantly coming in contact with biomedical waste, spillage and needle stick injuries. They can develop, implement, and evaluate a plan to reduce needle stick injuries in the institution, and evaluate needle devices with safety features. Hence it is important to know the knowledge of nurses in biomedical waste management, spillage and needle stick injury management.

\section{Materials and M ethods}

The study was conducted after obtaining the ethical clearance and permission from the Chief Nursing Officer among registered staff nurses who have the clinical experience for more than a month in all the wards such as Intensive Care Units, Dialysis unit, Post operative, Medical, Surgical, Orthopaedic, Paediatric, Oncology, Obstetrical and Gynecological, Psychiatric wards and Deaddiction centre of Father Muller Medical College Hospital, Mangalore. Nursing Supervisors, Ward incharges, Night duty staffs were excluded from the study. Baseline variables and structured knowledge questionnaire used to assess the knowledge regarding hospital protocols on bio-medical waste management, needle stick injury and spillage.

\section{Results}

Descriptive and inferential statistics will be used for the data analysis.
Table 1 : Frequency and percentage distribution of staff nurses according to of baseline variables.

$\mathrm{N}=210$

\begin{tabular}{|c|c|c|c|}
\hline SL.NO & VARIABLES & FREQUENCY (F) & PERCENTAGE (\%) \\
\hline 1 & $\begin{array}{l}\text { Age } \\
\text { - 20-23 years } \\
\text { - 24-27 years } \\
\text { - 28-32 years } \\
\text { - >32 years }\end{array}$ & $\begin{array}{c}89 \\
115 \\
5 \\
1\end{array}$ & $\begin{array}{c}42.38 \% \\
54.76 \% \\
2.38 \% \\
0.48 \%\end{array}$ \\
\hline 2 & $\begin{array}{l}\text { Gender } \\
\text { - Male } \\
\text { - Female }\end{array}$ & $\begin{array}{c}10 \\
200\end{array}$ & $\begin{array}{c}4.76 \% \\
95.24 \%\end{array}$ \\
\hline 3 & $\begin{array}{l}\text { Qualification } \\
\text { - GNM staff nurse } \\
\text { - BSc staff nurse } \\
\text { - MSc staff nurse } \\
\text { - PCBSC staff nurse }\end{array}$ & $\begin{array}{c}70 \\
125 \\
0 \\
15\end{array}$ & $\begin{array}{c}33.33 \% \\
59.52 \% \\
0 \% \\
7.14 \% \\
\end{array}$ \\
\hline 4 & \begin{tabular}{|l|} 
Year of clinical expe \\
- 6 months- 1 year \\
- $1-2$ years \\
- $3-5$ years \\
- >5 years
\end{tabular} & $\begin{array}{c}\text { rience } \\
49 \\
134 \\
20 \\
7\end{array}$ & $\begin{array}{c}23.33 \% \\
63.81 \% \\
9.52 \% \\
3.33 \%\end{array}$ \\
\hline 5 & \begin{tabular}{|l|} 
Special educational \\
- Attended \\
- Not attended \\
Duration : \\
- $\quad$ Less than a year \\
- Before1-2 years \\
- Before 3-6 years \\
Type: \\
- Workshop \\
- Conference \\
- Inservice \\
- education \\
Others
\end{tabular} & $\begin{array}{c}\text { programme } \\
191 \\
19 \\
\\
161 \\
21 \\
20 \\
\\
14 \\
44 \\
126 \\
26\end{array}$ & $\begin{array}{c}90.95 \% \\
9.04 \% \\
76.66 \% \\
10 \% \\
9.52 \% \\
\\
6.66 \% \\
20.95 \% \\
60 \% \\
12.38 \%\end{array}$ \\
\hline
\end{tabular}

Table 2 : Mean, and standard deviation of the staff nurses knowledge on spillage, biomedical waste management and needlestick injury.

\begin{tabular}{|l|c|c|c|}
\hline Variables & $\begin{array}{c}\text { Maximum } \\
\text { score }\end{array}$ & Mean & $\begin{array}{c}\text { Standard } \\
\text { deviation }\end{array}$ \\
\hline $\begin{array}{l}\text { Knowledge level on : } \\
\text { Biomedical } \\
\text { waste } \\
\text { management } \\
\text { Spillage } \\
\text { management }\end{array}$ & 13 & 9.09 & 1.86 \\
$\begin{array}{l}\text { Needle } \\
\text { stick injury }\end{array}$ & 5 & 3.4 & 0.98 \\
\hline
\end{tabular}

Table 2 reveals that the mean value of the knowledge of staff nurses on biomedical waste management is $9.09 \pm 1.86$, mean value of knowledge of nurses on spillage management is $7.4 \pm 1.56$ and the mean value of knowledge of nurses on needle stick injury is $3.4 \pm 0.98$. 
Knowledge of staff nurses on bio medical waste management, spillage management and needle stick injury

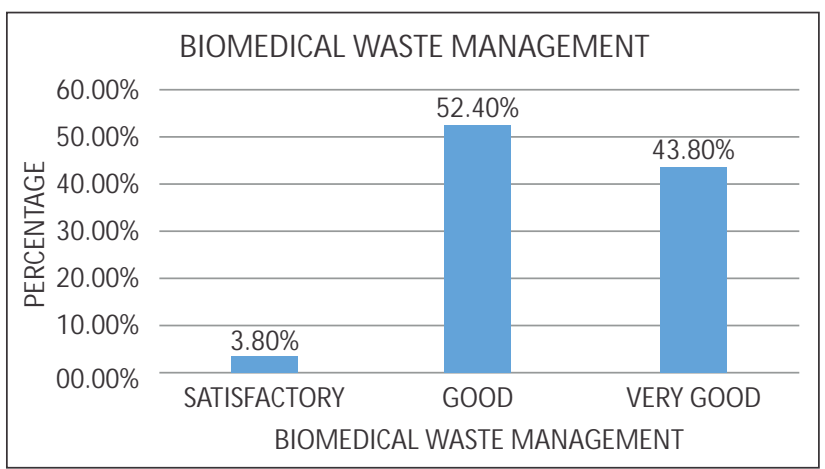

Fig. 1 : Bar diagram showing the distribution of staff nurses based on the knowledge on biomedical waste management

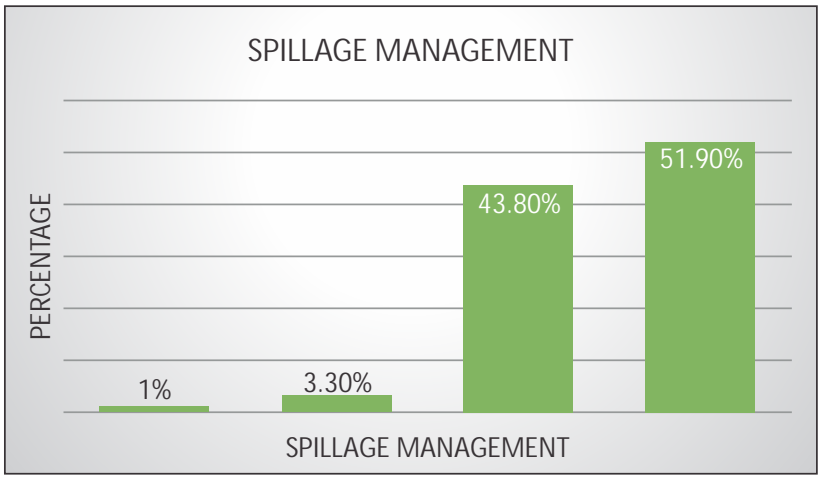

Figure 2 : Bar diagram showing the distribution of staff nurses based on the knowledge regarding spillage management.

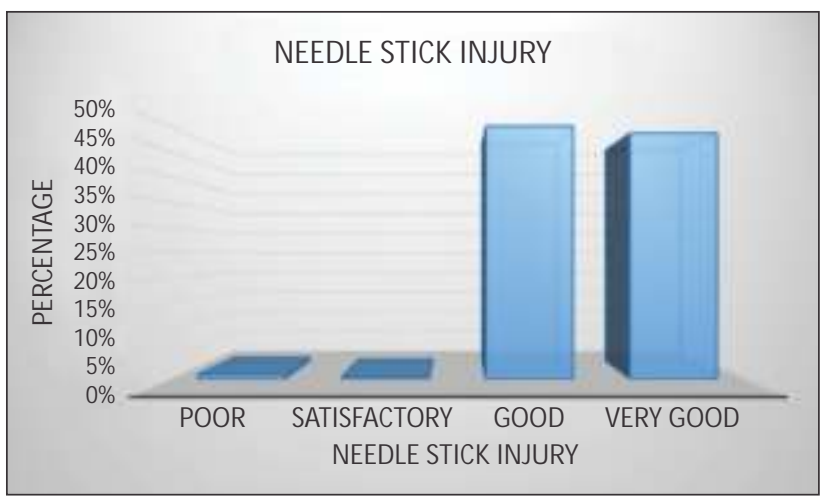

Figure 3 : Bar diagram showing the distribution of staff nurses based on the knowledge regarding needle stickinjury.

\section{Discussion}

The present study shows that the majority of the subjects are female (95\%) and most of the subjects were completed graduation B.Sc. (59.52\%) $63.80 \%$ had six months to two years of clinical experience. The study shows that $90.95 \%$ are attended educational programme, in that $80.48 \%$ attended before one to two years. The result of the present study reveals that mean percentage of the knowledge of registered staff nurses regardinghospital protocols on bio-medical waste management, needle stick injury and spillage is (78.6\%) which in turn shows that they have good level of knowledge on bio-medical waste management, needle stick injury and spillage. Comparing the study done earlier in Mangalore on the knowledge and practices of health care providers on bio-medical waste management, most of the interviewers were aware of the measures for safe collection, segregation and disposal of BMW. Highest percentage regarding knowledge on BMW management was seen among the nurses (61.3\%) followed by doctors (46.6\%), non-teaching staffs (37.7\%) and lab technicians(27.9\%).

\section{Conclusion}

India generates around three million tones of medical wastes every year and the amount is expected to grow at eight per cent annually. Biomedical waste management, needle stick injury and management of spillage are part of infection control and it is generated from the biological and medical sources and activities, such as the diagnosis, prevention or treatment of diseases. Common producers of biomedical waste include hospitals, health clinics, nursing homes, medical research laboratories etc. Nurses as part of health team plays a key role in managing the biomedical waste management.

\section{References}

1. Khushdil, Arshad, Farruk, Huma, 'Journal of Post Graduate Medical Institute, 2013, Vol 27, Issue 4,Pub :Oct 2013,381

2. YadavannavarMC ,Berad Aditya $S$, Jagirdar PB, Indian Journal Community Medicine : Official Publication Of Indian association of preventive and social medicine' , Jan 2010, M edknow Publication ,170 $-1$

3. SuwarnaMadhukumar, Ramesh G , 'International Journal of Basic Medical Science' , April 2012, Vol 3, Issue 1, 7-11

4. Bhargava A, 'International J ournal of health care Quality Assurance', Jan 1,2013, Medline Pub , 149-58

5. Siddique K,M irzaShirin, M alikAZ, ' Pakistan Journal Of Surgery, Vol 24 , Issue 4, 2008, 243- 48

6. Health care wide hazards Needle stick/sharp injuries.Retrieved from: https://www.osha.gov/SLTC/etools/hospital/hazards/sharps/ sharps.html6 